\title{
NMNAT Proteins that Limit Wallerian Degeneration Also Regulate Critical Period Plasticity in the Visual Cortex
}

\author{
[D Mariska van Lier, ${ }^{1 *}$ Laura Smit-Rigter, ${ }^{1 "}$ Roos Krimpenfort, ${ }^{1}{ }^{\circledR}$ M. Hadi Saiepour, ${ }^{1}$ Emma Ruimschotel, ${ }^{1}$ \\ Willem Kamphuis, ${ }^{3}$ 니. Alexander Heimel, ${ }^{2}$ and ${ }^{-C h r i s t i a a n ~ N . ~ L e v e l t ~}{ }^{1,4}$
}

https://doi.org/10.1523/ENEURO.0277-18.2018

\begin{abstract}
${ }^{1}$ Molecular Visual Plasticity Group, Netherlands Institute for Neuroscience, Meibergdreef 47, 1105 BA Amsterdam, The Netherlands, ${ }^{2}$ Cortical Structure and Function Group, Netherlands Institute for Neuroscience, Meibergdreef 47, 1105 BA Amsterdam, The Netherlands, ${ }^{3}$ Netherlands Institute for Neuroscience, Meibergdreef 47, 1105 BA Amsterdam, The Netherlands, and ${ }^{4}$ Department of Molecular and Cellular Neurobiology, Center for Neurogenomics and Cognitive Research, Vrije Universiteit Amsterdam, De Boelelaan 1105, 1081 HV Amsterdam, The Netherlands
\end{abstract}

\begin{abstract}
Many brain regions go through critical periods of development during which plasticity is enhanced. These critical periods are associated with extensive growth and retraction of thalamocortical and intracortical axons. Here, we investigated whether a signaling pathway that is central in Wallerian axon degeneration also regulates critical period plasticity in the primary visual cortex (V1). Wallerian degeneration is characterized by rapid disintegration of axons once they are separated from the cell body. This degenerative process is initiated by reduced presence of cytoplasmic nicotinamide mononucleotide adenylyltransferases (NMNATs) and is strongly delayed in mice overexpressing cytoplasmic NMNAT proteins, such as WId ${ }^{\mathrm{S}}$ mutant mice producing a UBE4b-NMNAT1 fusion protein or NMNAT3 transgenic mice. Here, we provide evidence that in Wld ${ }^{\mathrm{S}}$ mice and NMNAT3 transgenic mice, ocular dominance (OD) plasticity in the developing visual cortex is reduced. This deficit is only observed during the second half of the critical period. Additionally, we detect an early increase of visual acuity in the V1 of Wld ${ }^{\mathrm{S}}$ mice. We do not find evidence for Wallerian degeneration occurring during OD plasticity. Our findings suggest that NMNATs do not only regulate Wallerian degeneration during pathological conditions but also control cellular events that mediate critical period plasticity during the physiological development of the cortex.
\end{abstract}

Key words: axon; cortex; critical period; plasticity; Wallerian degeneration

\section{Significance Statement}

Different forms of axon degeneration occur during development and neurodegenerative processes. A good understanding of the molecular and cellular events that regulate these forms of axon degeneration is essential to selectively modulate them for therapeutic purposes. This study shows that genes thought to be selectively involved in pathologic axon degeneration are also involved in developmental plasticity, implying that these events are molecularly less separable than previously assumed.

\section{Introduction}

Many regions of the brain go through defined phases of development, known as critical periods, during which

Received July 17, 2018; accepted December 4, 2018; First published January 04, 2019.

The authors declare no competing financial interests. experience-dependent plasticity is enhanced. Plasticity deficits during these critical periods have lifelong consequences. Understanding the molecular and cellular mech- 
anisms that control critical period closure may help the development of approaches to reopen critical periods at a later age for therapeutic purposes. The most informative model to study critical period regulation has been ocular dominance (OD) plasticity in mouse primary visual cortex (V1). OD plasticity occurs during development to optimize binocular vision, matching the inputs of both eyes and, if this is not possible, biasing V1 toward inputs from the eye providing the most reliable inputs. When one eye is monocularly deprived (MD) for several days, developing V1 adjusts to this situation by rearranging thalamocortical and corticocortical connectivity. This results in a shift of responsiveness of V1 neurons toward the open eye (Gordon and Stryker, 1996; Antonini et al., 1999; Haruta and Hata, 2007). In adult mice in which the critical period in V1 is closed, prolonged MD causes a weaker and less permanent shift (Sawtell et al., 2003; Hofer et al., 2006; Heimel et al., 2007; Lehmann and Löwel, 2008; Sato and Stryker, 2008). Over the last two decades, this model revealed that maturation of inhibitory innervation is the dominant mechanism regulating critical period closure. However, various other cellular events have been implicated in critical period closure, including excitatory synapse maturation (Tropea et al., 2010; Bochner et al., 2014; Stephany et al., 2014; Huang et al., 2015; Jenks et al., 2017), extracellular matrix development (Pizzorusso et al., 2002), CREB transcription (Pham et al., 2004; Tognini et al., 2011), neuromodulatory inputs (Bear and Singer, 1986; Morishita and Hensch, 2008; Vetencourt et al., 2008), and declining neurite growth and retraction (McGee et al., 2005; Syken et al., 2006).

In a study analyzing changes in the synaptic proteome during development and OD plasticity of $\mathrm{V} 1$, several proteins involved in Wallerian axon degeneration were identified, whose expression levels changed around the time of critical period closure (Dahlhaus et al., 2011). Wallerian degeneration typically occurs after the nerve is separated from the cell body after injury (Kerschensteiner et al., 2005; Coleman and Freeman, 2010; Pease and Segal, 2014; Geden and Deshmukh, 2016; Gerdts et al., 2016). Because retraction of thalamocortical and intracortical axons also occurs in V1 during OD plasticity, we were intrigued by the possibility that the signaling pathway that mediates Wallerian degeneration also regulates axonal reorganization during OD plasticity.

During Wallerian degeneration, disintegration of the axon starts by breakdown of the cytoskeleton, followed

This work was supported through a grant from AgentschapNL to the NeuroBasic PharmaPhenomics consortium, The Netherlands Organisation for Scientific Research (NWO) Grant 823.02.001, a grant from Stichting Blindenhulp, a donation from Praktijkgenerator b.v., and a Vidi grant (to J.A.H.)

${ }^{\star}$ M.v.L. and L.S.R. contributed equally to this work.

Acknowledgements: We thank Toshiyuki Araki for donating the NMNAT1 and NMNAT3 transgenic mice.

Correspondence should be addressed to Christiaan N. Levelt at c.levelt@nin.knaw.nl.

https://doi.org/10.1523/ENEURO.0277-18.2018

Copyright (C) 2019 van Lier et al.

This is an open-access article distributed under the terms of the Creative Commons Attribution 4.0 International license, which permits unrestricted use, distribution and reproduction in any medium provided that the original work is properly attributed. by degradation of the myelin sheath (Vargas and Barres, 2007; Gilley and Coleman, 2010). Nicotinamide mononucleotide adenylyltransferases (NMNATs), key proteins in the nicotinamide adenine dinucleotide (NAD) biosynthetic pathway, are implicated in regulating Wallerian degeneration. Wallerian degeneration is slowed down considerably in Wld ${ }^{S}$ mice, which carry a spontaneous mutation causing overexpression of an axonally targeted UBE4bNMNAT1 fusion protein (Coleman et al., 1998; Lunn et al., 1989; Lyon et al., 1993; Conforti et al., 2000, 2007, 2009). NMNAT3, which is localized in mitochondria, can also protect against Wallerian degeneration when overexpressed in transgenic mice (Yahata et al., 2009). Interestingly, neither NMNAT1 nor NMNAT3, but NMNAT2 is required for axon integrity (Gilley and Coleman, 2010). After axons are injured, NMNAT2 expression rapidly declines promoting axon degeneration (Araki et al., 2004; Sasaki et al., 2006; Babetto et al., 2013).

Previous work found that axonal pruning during early development was not altered in $\mathrm{Wld}^{\mathrm{S}}$ mice and flies overexpressing the Wld ${ }^{S}$ protein (Hoopfer et al., 2006). This suggested that Wallerian degeneration only occurs after injury and not during development. However, it has become clear that early cortical development driven by spontaneous activity and critical period plasticity driven by experience are regulated by different molecular and cellular mechanisms (Hensch, 2005; Levelt and Hübener, 2012; Lohmann and Kessels, 2014). Therefore, we wanted to reassess the premise that the Wallerian degeneration signaling pathway is not involved in normal development of the brain.

To this aim, we assessed whether OD plasticity is altered in mouse lines in which Wallerian degeneration is reduced due to overexpression of cytoplasmic NMNAT overexpression. We find that in mice overexpressing NMNAT in the cytoplasm, OD plasticity is reduced during the second half of the critical period but not during the first half. Moreover, we find that cortical visual acuity in Wld ${ }^{S}$ is already high at a young age. At the same time, we find that OD plasticity does not cause hallmark signatures of Wallerian degeneration. Together, these results suggest that genes that regulate Wallerian degeneration also regulate developmental events in the visual cortex.

\section{Materials and Methods}

\section{Animals}

We made use of mice overexpressing the $\mathrm{Wld}^{\mathrm{S}}$ protein, NMNAT1 (nuclear isoform) or NMNAT3 (mitochondrial isoform; Yahata et al., 2009). The Wld ${ }^{S}$ line was originally derived from the $\mathrm{C} 57 \mathrm{BI} / 6 \mathrm{Ola} / \mathrm{hsd}$ mouse line and hence, these mice were used as wild-type controls for these mice. NMNAT1 and NMNAT3 mice were maintained on a C57BI6/j background and wild-type littermates were used as controls. Mice of either sex were used for all experiments. All experiments involving mice were approved by the institutional animal care and use committee.

\section{Surgical preparation}

For MD, the upper and lower lids of the right eye were clipped and sutured together with two mattress sutures 
during isoflurane anesthesia. During the procedure the eye was rinsed with saline and after suturing lidocaine cream was applied to the closed eyelid. At the start of an imaging session, the eyes were reopened. Animals which had early opening of the eye or a damaged eye were excluded from the experiments.

\section{Optical imaging and visual stimulation}

Optical imaging of intrinsic signal was performed as previously described (Heimel et al., 2007). Mice were anesthetized with an intraperitoneal injection of urethane (Sigma; 20\% solution in saline, $2 \mathrm{mg} / 10 \mathrm{~g}$ bodyweight). This was immediately followed by a subcutaneous injection of atropine sulphate (AUV; $50 \mu \mathrm{g} / \mathrm{ml}$ in saline, $1 \mu \mathrm{g} / 10$ $\mathrm{g}$ bodyweight) to reduce excretions from mucous membranes and chlorprothixene (Sigma; $2 \mathrm{mg} / \mathrm{ml}$ in saline, 80 $\mu \mathrm{g} / 10 \mathrm{~g}$ bodyweight). Sometimes a supplement of urethane of $\sim 10 \%$ of the initial dose was necessary to obtain a sufficient amount of anesthesia. Anesthetized mice were placed on a heating pad and body temperature was monitored with a rectal probe and maintained at $36.5^{\circ} \mathrm{C}$. A continuous flow of oxygen was provided close to the nose. The mouse was fixated by ear bars with conical tips and a bite rod behind the front teeth, $3 \mathrm{~mm}$ lower than the ear bars. The scalp was treated with xylocaine (lidocaine $\mathrm{HCl}, \mathrm{AUV}$ ), and part of the scalp was removed to expose the skull. The skull was cleaned using saline. Black cloth was used to prevent light from the monitor reaching the camera. Light from a tungsten-halogen lamp filtered through a KG-1 heat filter and a $700 \mathrm{~nm}$ (30 nm width) bandpass filter illuminated the skull. Reflecting light was caught by Adimec-1000m/D CCD camera behind a macroscope composed of two Nikkor $50 \mathrm{~mm} / \mathrm{f} 1.2$ lenses, focused 0.8 below the cranial surface, centred at $2.6 \mathrm{~mm}$ lateral and 0.5 rostral to lambda. Images, taken at $25 \mathrm{~Hz}$, were down sampled and stored $1.7 \mathrm{~Hz}$ by an Optimal Imager 3001 system (Optical Imaging Inc).

A $\gamma$-corrected Dell UltraSharp U2312HM 23" full HD LCD monitor was placed at $15 \mathrm{~cm}$ from the mouse' eye contralateral to the imaged hemisphere covering $-15-75^{\circ}$ horizontally and $-45-45^{\circ}$ vertically of the visual field. Background luminance was $5 \mathrm{~cd} \mathrm{~m}^{-2}$. For obtaining a coarse retinotopic map, the screen was divided in two by two rectangles. Square wave, $90 \%$ contrast, gratings of 0.05 cycles per degree drifting at $40^{\circ}$ per second and changing drifting directions every $0.6 \mathrm{~s}$, were intermittingly shown for $6 \mathrm{~s}$ every $15 \mathrm{~s}$ in one of the quadrants, on an equiluminant gray background, for $\sim 15$ repetitions. For measuring OD, the same square wave gratings were shown in the superior-nasal quadrant, for $3 \mathrm{~s}$ per stimulation. Using automated eye shutters, vision was allowed through the left, the right or no eye (to check the completeness of the vision block) in random order (at least 40 repetitions for each condition). Acuity was measured by stimulating the contralateral eye with sinusoidal, $90 \%$ contrast, gratings of various spatial frequencies, for at least 40 repetitions. Visual stimuli were separated by periods of equiluminant gray of at least $12 \mathrm{~s}$.

Image analysis was done by first subtracting signal average of the last $3 \mathrm{~s}$ before stimulation. To remove global slow biological fluctuations, this signal was normalized by changes occurring in a reference region outside of visual cortex. For each pixel, the response was computed as the negative of this average signal during the visual stimulation. For retinotopic mapping, each pixel received a color corresponding to the quadrant to which the signal was highest. Using this map, the area corresponding to the superior-nasal quadrant was manually selected as $\mathrm{ROI}$ for the OD and acuity measurements. The response in these tests was taken as the mean response over all pixels in this ROI. The imaged OD index (iODI) was defined as (contra-response - ipsi-response)/(contra-response + ipsi-response). The acuity was defined by the intercept with the spatial frequency axis after fitting the spatial frequency tuning curve with a downward sloping threshold linear function.

\section{Immunohistochemistry}

Age matched mice were anesthetized with $0.1 \mathrm{ml} / \mathrm{g}$ body weight Nembutal (Janssen) and perfused with $4 \%$ paraformaldehyde (PFA) in PBS ( $\sim 80 \mathrm{ml}$ per mouse) and postfixed for $2-3 \mathrm{~h}$. Coronal sections of $50 \mu \mathrm{m}$ were made by using a vibratome (Leica VT1000S). Antibodies used were against synaptotagmin-2 (rabbit, 1:1000, a kind gift from Dr. T. Südhof) followed by Alexa Fluor 568conjugated goat anti-rabbit antibody (1:000, A11011, Invitrogen) or the F4/80 marker for activated microglia (mouse, 1:200, MCA497, Bio-Rad) followed by Alexa Fluor 568-conjugated goat anti-mouse antibody (1:500, A11004, Invitrogen). All antibodies were previously tested in mice for the application we used them for (more information can be found in the references or on the websites of the suppliers). Free-floating sections were briefly washed in PBS followed by $1 \mathrm{~h}$ blocking in PBS containing $5 \%$ normal goat serum and $0.1 \%$ Triton $\mathrm{X}-100$. Primary antibody incubation was performed overnight at $4^{\circ} \mathrm{C}$ in fresh blocking solution. Next, the sections were washed three times for 10 min in PBS with $0.1 \%$ Tween 20 (PBST) followed by secondary antibody incubation in fresh blocking solution for $90 \mathrm{~min}$ at room temperature (RT). After washing three times for 10 min in PBST, the sections were mounted on glass slides using Mowiol (Calbiochem/MerckMillipore) and glass covered for imaging.

\section{Confocal microscopy and data analysis}

For quantification of synaptotagmin-2 puncta number, fluorescent puncta were analyzed using a noncommercially available macro for Image-Pro PLUS (v6.3). Up to six puncta rings per image obtained from V1 sections were manually encircled after which a mask was created on the cell. A 2- $\mu \mathrm{m}$-wide ring was calculated around the mask and all puncta in the ring were considered to belong to the cell and were counted and measured. Signals not reaching size and fluorescent threshold levels were omitted. Pixel intensity for the signal within masks was considered background and subtracted from the intensity values in the puncta. Puncta numbers were analyzed per image. For quantification of the number of activated microglia, the number of microglia cells were manually counted in images obtained from V1 sections. 
A

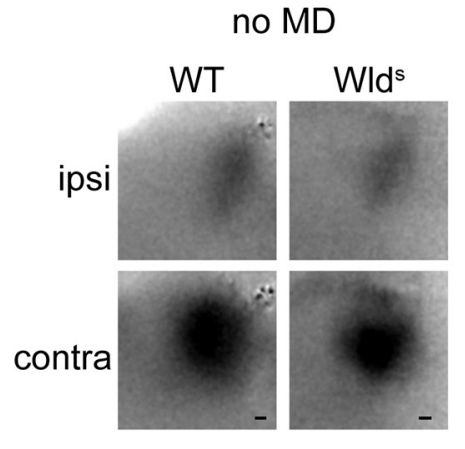

P28-P35

$7 \mathrm{~d} M D$

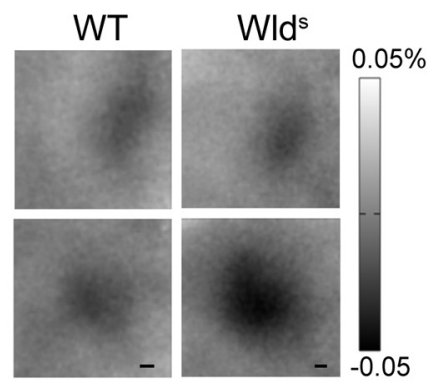

P20-P27

c no MD

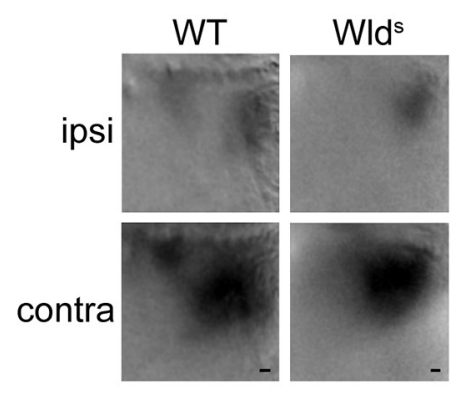

$7 \mathrm{~d} M D$

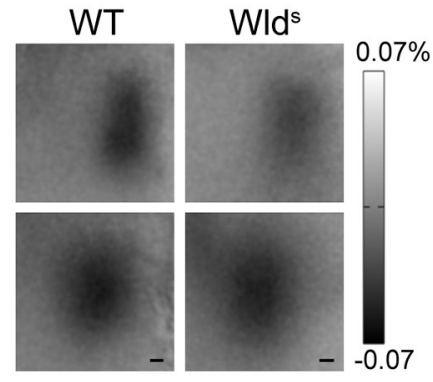

B

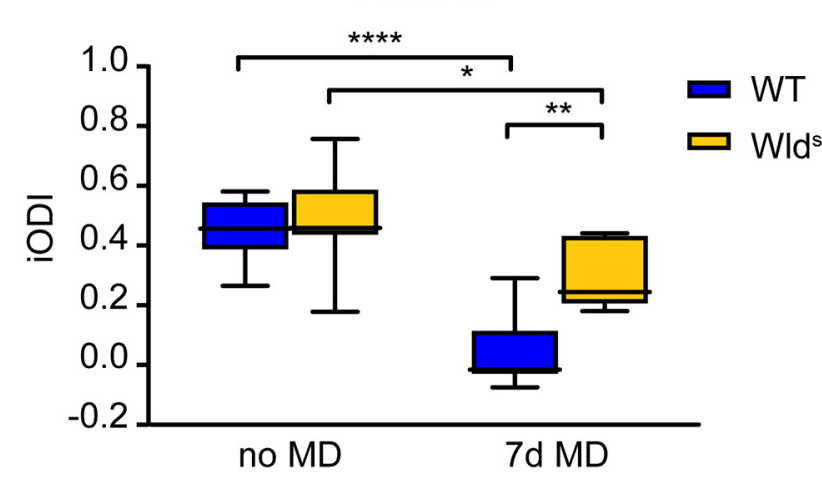

D

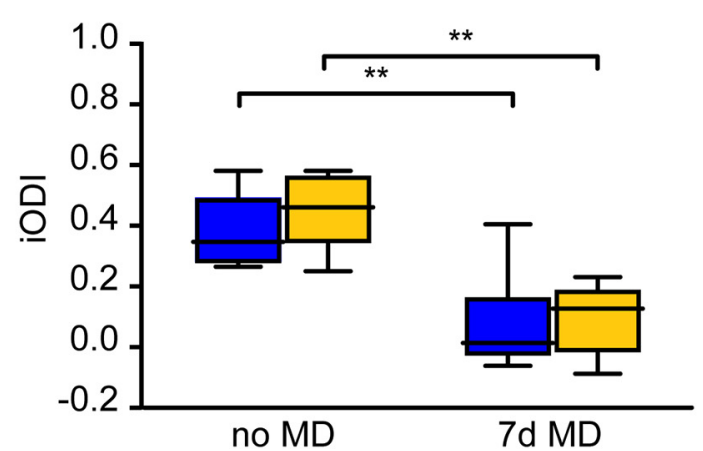

Figure 1. Wld ${ }^{S}$ mutant mice have reduced OD plasticity during the critical period. $\boldsymbol{A}$, Transcranial images of change in light reflection in V1, in response to individual eye stimulation in non-deprived (no MD) and 7 D-deprived (7d MD) wild-type (WT) and WId ${ }^{\mathrm{S}}$ mice, during the peak of the critical period at P28-P35. B, iODI shows that 7d MD induces a larger OD shift in WT mice than in WId ${ }^{\mathrm{S}}$ mutant mice (interaction genotype/OD-shift: two-way ANOVA, $p=0.0029$, post hoc Tukey's, WT vs WT MD, $p<0.0001$, WId ${ }^{\mathrm{S}}$ vs WId $^{\mathrm{S}} \mathrm{MD}^{\mathrm{N}}$, $p=0.0114$, WT MD vs Wld ${ }^{\mathrm{S}} \mathrm{MD}, p=0.0034$, WT: $n=12$ mice, Wld ${ }^{\mathrm{S}}: n=9$ mice, WT MD: $n=8$ mice, Wld $^{\mathrm{S}}$ MD: $n=7$ mice). C, Transcranial images of change in light reflection in V1, in response to individual eye stimulation in no MD and $7 \mathrm{~d}$ MD WT and WId mice, before the peak of the critical period. $\boldsymbol{D}$, Imaged ODIs show that earlier in development MD induces an OD shift in both WT and $\mathrm{Wld}^{\mathrm{S}}$ mice, with no significant difference between the genotypes (interaction genotype/OD-shift: two-way ANOVA, $p=0.4018$; interaction treatment/OD-shift: $p<0.0001$, post hoc Tukey's, WT vs WT MD, $p=0.0022$, WId ${ }^{\mathrm{S}}$ vs WId $^{\mathrm{S}}$ MD, $p=0.0021$. WT: $n=$ 8 mice, Wld ${ }^{S}: n=5$ mice, WT MD: $n=6$ mice, Wld ${ }^{S}$ MD: $n=5$ mice). Values shown as median (solid line), \pm 1.5 interquartile range (box) and minimal and maximal values (whiskers). Scale bars, $200 \mu \mathrm{m} ; * p<0.05, * * p<0.01, * * * * p<0.0001$.

An area of $387.5 \times 387.5 \mu \mathrm{m}$ was counted. Only cells of which the soma was visible were included.

\section{qPCR}

RNA was isolated from tissue containing V1 from both control and Wld ${ }^{\mathrm{S}}$ mice using the mirVana miRNA isolation kit (Invitrogen). Total RNA (200 ng) was DNase I treated and used as a template to generate cDNA following the manufacturer's instructions (QuantiTect Reverse Transcription kit; QIAGEN) with a blend of oligo-dT and random primers. The reverse transcriptase reaction was incubated at $42^{\circ} \mathrm{C}$ for $30 \mathrm{~min}$ and terminated at $95^{\circ} \mathrm{C}$ for 3 min. The resulting CDNA was diluted 1:20 and served as a template in real-time qPCR assays (SYBR-Green PCR Master Mix; Applied Biosystems). Primers were generated for GAD65 and tested for efficiency. The determined transcript levels of these target genes were normalized against the levels of GAPDH determined in the same sample to control for variability in the amount and quality of the RNA and the efficiency of the cDNA reaction.

\section{Slice electrophysiology}

Mice were anesthetized using isoflurane and then decapitated. Brains were quickly removed and kept at $0^{\circ} \mathrm{C}$ in carbogenated $\left(95 \% \mathrm{O}_{2} / 5 \% \mathrm{CO}_{2}\right)$ modified ACSF containing choline chloride $(110 \mathrm{mM}$ choline chloride, 7 $\mathrm{mM} \mathrm{MgCl}_{2}, 0.5 \mathrm{mM} \mathrm{CaCl}_{2}, 2.5 \mathrm{mM} \mathrm{KCl}, 11.6 \mathrm{mM} \mathrm{Na}-$ ascorbate, $3.10 \mathrm{mM}$ Na-pyruvate, $1.25 \mathrm{mM} \mathrm{NaH}_{2} \mathrm{PO}_{4}, 25$ $\mathrm{mM}$ D-glucose, and $25 \mathrm{mM} \mathrm{NaHCO}$ ), to prevent axon potentials in the brain during stressful conditions; 330$\mu \mathrm{m}$-thick coronal slices containing the visual cortex were cut on a vibratome (Microm HM650V; Thermo Scientific) while keeping the slices in carbogenated modified ACSF (125 mM NaCl, $3 \mathrm{mM} \mathrm{KCl}, 2 \mathrm{mM} \mathrm{MgSO}_{4}, 2 \mathrm{mM} \mathrm{CaCl}_{2}, 10$ $\mathrm{mM}$ glucose, $1.20 \mathrm{mM} \mathrm{NaH}_{2} \mathrm{PO}_{4}$ and $26 \mathrm{mM} \mathrm{NaHCO}_{3}$ ) at $0^{\circ} \mathrm{C}$. After slicing, all slices were kept in ACFS at $35^{\circ} \mathrm{C}$ for 30-45 min for recovery, while continuously bubbled with carbogen. Next, slices were kept in continuously carbogenated ACSF at RT until use (1-6 h after slicing). To perform electrophysiological experiments, slices were moved to a chamber with continuous inflow and outflow 
of carbogenated ACSF at a rate of $1-2 \mathrm{ml} / \mathrm{min}$ at RT. For all experiments, a layer $2 / 3$ pyramidal neuron in the visual cortex was patched. A glass pipette with a resistance between 3 and $6 \mathrm{M} \Omega$ was filled with intracellular solution containing $1 \mathrm{mg} / \mathrm{ml}$ biocytin for post hoc staining of the patched cell. After obtaining a gigaOhm seal, whole-cell patch clamp recordings were performed using Axopatch 1D (Molecular Devices). When the cell was patched, several currents were injected to see whether a cell was healthy and whether it showed a firing pattern typical for a pyramidal neuron. Before recording miniature EPSCs (mEPSCs), the bath solution was replaced with ACSF containing $1 \mu \mathrm{M}$ TTX to block all voltage dependent sodium currents and $20 \mu \mathrm{M}$ gabazine to block all $\mathrm{GABA}_{\mathrm{A}}$ receptors. For all experiments, cells were clamped at -70 $\mathrm{mV}$, and mEPSCs were measured during $5 \mathrm{~min}$. Mini Analysis (Synaptosoft Inc.) was used for analyzing mEPSCs. Recordings were included when the seal resistance $>1 \mathrm{G} \Omega$, the series resistance was smaller than $20 \mathrm{M} \Omega$, the whole cell capacitance was smaller than $150 \mathrm{pF}$, the resting potential was more negative than $-60 \mathrm{mV}$, and the RMS noise was $<2.5 \mathrm{pA}$ (threshold cutoff in MiniAnalysis was set at 6 , which is $2-2.5$ times the value of the RMS noise), before and after recording.

\section{Western blot analysis}

V1 from Wld ${ }^{\mathrm{S}}$ and control mice and the binocular part of V1 from control mice with or without MD were collected and homogenized in lysis buffer (LB) containing $150 \mathrm{mM}$ sodium chloride, $1 \%$ Triton $\mathrm{X}-100,50 \mathrm{mM}$ Tris, $\mathrm{pH} 8$, and a protease inhibitor cocktail (cOmplete Mini EDTA-Free, Roche), using an electric homogenizer (IKA). Proteins were purified by centrifugation $(1000 \times g)$, and the supernatant was collected. Protein content was measured by comparing with a bovine serum albumin standard using a bicinchoninic acid (BCA) reaction kit (Thermo Fisher Scientific/Pierce), and the optical density of the reagent was measured with an iEMS Reader MF (Labsystems/Thermo Scientific). Western blotting was performed using the NuPAGE Novex Bis-Tris pre-cast gel kit with a $4-12 \%$ gradient or the NuPAGE Novex Tris-acetate pre-cast gel kit with a 3-8\% gradient, in Invitrogen gel containers (Invitrogen). Gels were loaded with $60-\mu \mathrm{g}$ protein and run for 1 $\mathrm{h}$ at $200 \mathrm{~V}$ (Bis-Tris gel) or $150 \mathrm{~V}$ (Tris-acetate gel). After separation, gels were transferred at $14 \mathrm{~V}$ overnight to PVDF Immobilon-FL transfer membranes (Millipore). Protein membrane blots were stained with antibodies against synapsin 1 (rabbit, 1:250, ab64581), synaptotagmin-2 (mouse, 1:250, znp-1, ZIRC), NMNAT2 (mouse, 1:50, $B_{10}$, Santa Cruz Biotechnology), MYCBP2 (rabbit, 1:500, ab86078, Abcam), and GAPDH (mouse, 1:1000,MAB374, Merck) and analyzed using infrared secondary antibodies (LI-COR Biosciences) and the Odyssey Infrared Imaging System (LI-COR). Imaged bands were measured using the Odyssey application software and corrected for background intensities from adjacent non-labeled lanes.

\section{Statistics}

We determined that the imaged OD index values were normally distributed using the Shapiro-Wilk test. For testing differences in OD plasticity between transgenic and
A

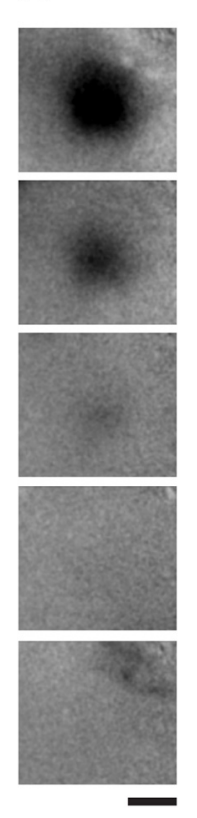

B

cpd

0.1

0.2

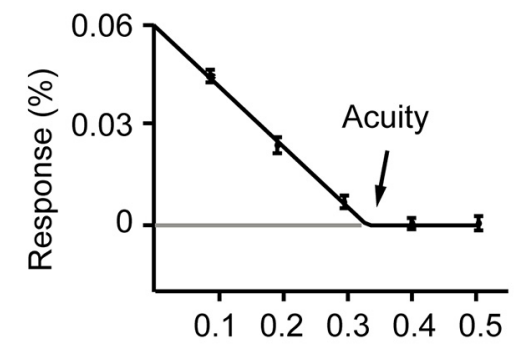

0.3

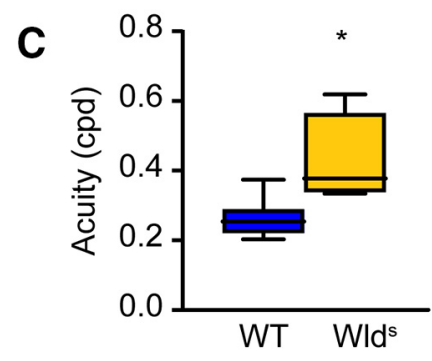

Figure 2. Early increase of visual acuity in $\mathrm{Wld}^{\mathrm{S}}$ mice. $\boldsymbol{A}$, Transcranial images of light reflection in $\mathrm{V} 1$, in response to visual stimulation using sinusoidal gratings with different spatial frequencies in cycles per degree (cpd). Scale bar, $1 \mathrm{~mm}$. $\boldsymbol{B}$, Example of cortical responses and the inferred acuity of a wild-type (WT) mouse. $\boldsymbol{C}$, Acuity of V1 responses is significantly increased in Wld ${ }^{\mathrm{S}}$ mutant mice compared to WT mice at P25 ( $t$ test, $p=$ 0.015 , WT: $n=7$, Wld $\left.{ }^{\mathrm{S}}: n=4\right)$.

control mice, we computed whether there was a significant interaction in a two-way ANOVA. For graphical representation of significant differences between groups, we presented the results of post hoc Tukey-Kramer tests. Because puncta number and density, mEPSCs, Western blotting data, and GAD65 mRNA levels were normally distributed (Shapiro-Wilk test), we used $t$ test when two independent groups were compared.

\section{Results}

\section{Reduced OD plasticity in WId ${ }^{\mathbf{S}}$ mice}

We first set out to investigate whether the Wld ${ }^{S}$ mutation affects OD plasticity. To this end, we used optical imaging of intrinsic signal to determine the OD in V1 of $\mathrm{WId}^{\mathrm{S}}$ mice and control $\mathrm{C} 57 \mathrm{BI} / 6 \mathrm{Ola} / \mathrm{hs}$ d mice that were either MD for $7 \mathrm{~d}$ during the peak of the critical period [postnatal day (P)28-P35] or reared normally. We found that $7 \mathrm{~d}$ of MD caused a stronger shift in OD in wild-type mice than in Wld ${ }^{S}$ mice (Fig. $1 A, B$ ). Thus, the Wld ${ }^{S}$ mutation interferes with efficient critical period plasticity in V1.

\section{Unaffected plasticity and higher visual acuity in V1 of young Wlds mice}

Axon degeneration involves the decreasing availability of NMNAT2 (Gilley and Coleman, 2010), a process that is enhanced by the Phr1 E3 ubiquitin ligase MYCBP2 (Babetto et al., 2013). Interestingly, MYCBP2 was found to down-regulate in V1 between P30 and P46 (Dahlhaus et al., 2011). It is thus possible that this leads to a gradual 
A

Layer 2/3
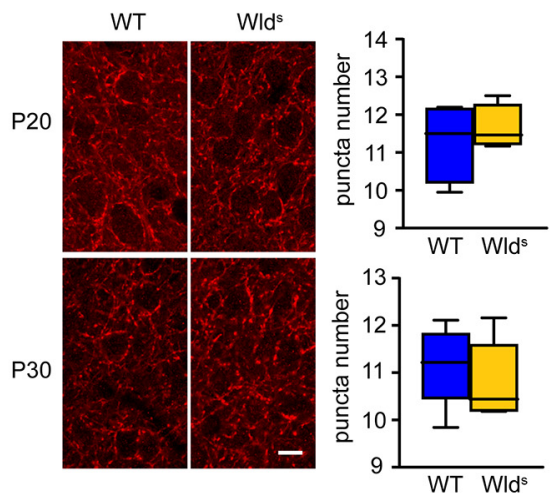

C

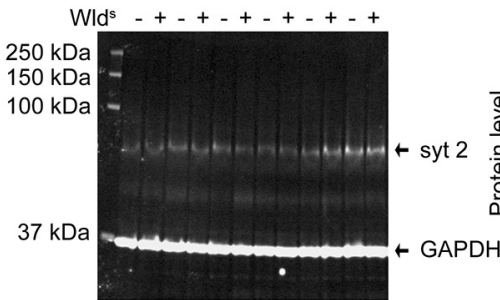

B

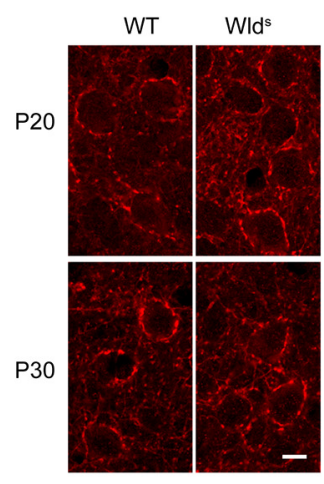

D
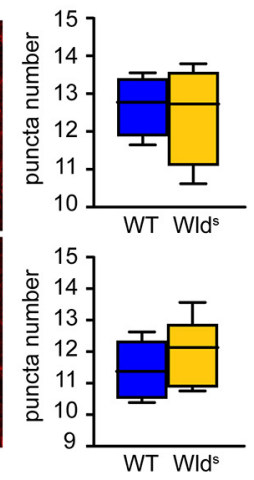

syt 2

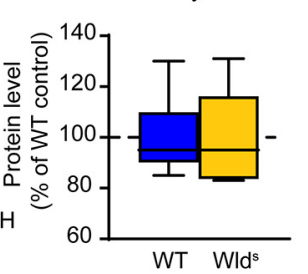

Gad2

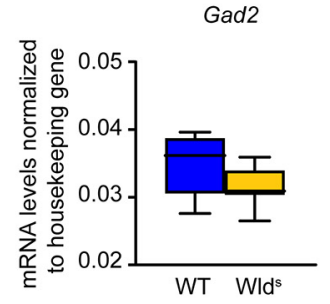

Figure 3. Normal development of inhibitory innervation in Wld ${ }^{\mathrm{S}}$ mice. $\boldsymbol{A}$, Representative images showing synaptotagmin-2 (syt 2)-positive puncta forming rings around cell bodies in cortical layers $2 / 3$ in wild-type (WT) and WId ${ }^{S}$ mice at P20 and P30. Number of syt 2-expressing boutons forming puncta rings in layers $2 / 3$ are unchanged in Wld ${ }^{S}$ mice compared to WT controls at P20 ( $t$ test, $p=0577, n=4$ for both genotypes) or P30 ( $p=0521, n=5$ for both genotypes). $\boldsymbol{B}$, Representative images showing syt 2-positive puncta forming rings around cell bodies in cortical layer 5 in WT and Wld ${ }^{S}$ mice at P20 and P30. Number of syt 2-expressing boutons forming puncta rings in layer 5 are unchanged in Wld ${ }^{S}$ mice compared to WT controls at P20 ( $t$ test, $p=0785, n=4$ for both genotypes), or P30 ( $p=0461, n=5$ for both genotypes). $C$, Representative examples of Western blot analysis of V1 and quantification of expression levels, normalized to those of WT control mice. Expression levels for syt 2 are unaltered at P30 ( $t$ test, $p=0.9869, n=$ 6 for both genotypes). $\boldsymbol{D}$, GAD65 mRNA expression levels relative to housekeeping gene is unchanged at P30 ( $p=0.089, \mathrm{WT}: n=$ 8 , Wld ${ }^{\mathrm{S}}: n=7$ ). Values shown as median (solid line), \pm 1.5 interquartile range (box) and minimal and maximal values (whiskers). Scale bars, $10 \mu \mathrm{m}$.

increase of axon stability contributing to declining plasticity. We therefore wanted to test whether the reduced plasticity observed in P28-P35 Wld $^{\mathrm{S}}$ mice was not a plasticity deficit per se, but a selective decline of plasticity during the later phase of the critical period. To this aim, we assessed whether at an earlier age, WId ${ }^{\mathrm{S}}$ mice did show OD plasticity. We again used optical imaging of intrinsic signal to determine the $\mathrm{OD}$ in $\mathrm{Wld}^{\mathrm{S}}$ mice and control $\mathrm{C} 57 \mathrm{BI} / 6 \mathrm{Ola} / \mathrm{hsd}$ mice that were reared normally, or MD for $7 \mathrm{~d}$, but now starting one week earlier (P20-P27). We found that $7 \mathrm{~d}$ of MD starting at P20 induced a full OD shift in $\mathrm{Wld}^{\mathrm{S}}$ mice, similar to what we observed in $\mathrm{C} 57 \mathrm{BI} / 6 \mathrm{Ola} /$ hsd mice (Fig. 1C,D). Therefore, we conclude that in $\mathrm{Wld}^{\mathrm{S}}$ mice, OD plasticity is not deficient as such, but is decreased during the second half of the critical period.

This finding suggested that other functional changes that normally occur around the end of the critical period may also take place at a younger age in Wld ${ }^{\mathrm{S}}$ mice. One such change is the increase in cortical visual acuity from $\sim 0.25 \mathrm{cpd}$ at P25 to over $0.5 \mathrm{cpd}$ at P35 (Gordon and Stryker, 1996; Huang et al., 1999; Gianfranceschi et al., 2003; Heimel et al., 2007). We determined acuity in both $\mathrm{Wld}^{\mathrm{S}}$ and control $\mathrm{C} 57 \mathrm{BI} / 6 \mathrm{Ola} / \mathrm{hsd}$ mice at P25, by making use of optical imaging of intrinsic signal (Fig. $2 A, B$ ). It was previously shown that at this age, visual acuity is still low in wild-type mice, but nearly at adult levels in mice overexpressing BDNF causing premature cortical development (Huang et al., 1999). Similarly, we observed that at P25, visual acuity in $\mathrm{Wld}^{\mathrm{S}}$ mice was significantly higher than in control mice ( 0.4 vs $0.25 \mathrm{cpd}$; Fig. $2 C$ ). Thus, acuity in $\mathrm{V} 1$ reaches high levels at a younger age in $\mathrm{Wld}^{\mathrm{S}}$ mice than in control mice.

\section{No evidence for altered inhibitory or excitatory synapse development in W/d ${ }^{\mathrm{s}}$ mice}

In BDNF-overexpressing mice, an early decline of OD plasticity and accelerated development of visual acuity was associated with accelerated development of the GABAergic inhibitory system (Hanover et al., 1999; Huang et al., 1999). One of the key players in the regulation of critical periods are the parvalbumin-expressing $(\mathrm{PV}+)$ basket cells (Chattopadhyaya, 2004; Fagiolini, 2004; Hensch, 2005; Kuhlman et al., 2013). The axon terminals of these PV + neurons form presynaptic boutons on the soma and proximal dendrites of their target neuron and the development of the puncta-rings that they form coincides with the critical period (del Río et al., 1994). We therefore set out to quantify the difference in perisomatic inhibition from $\mathrm{PV}+$ interneurons onto pyramidal neurons in layer $2 / 3$ and layer 5 of $\mathrm{V} 1$ in $\mathrm{Wld}^{\mathrm{S}}$ mice and control 

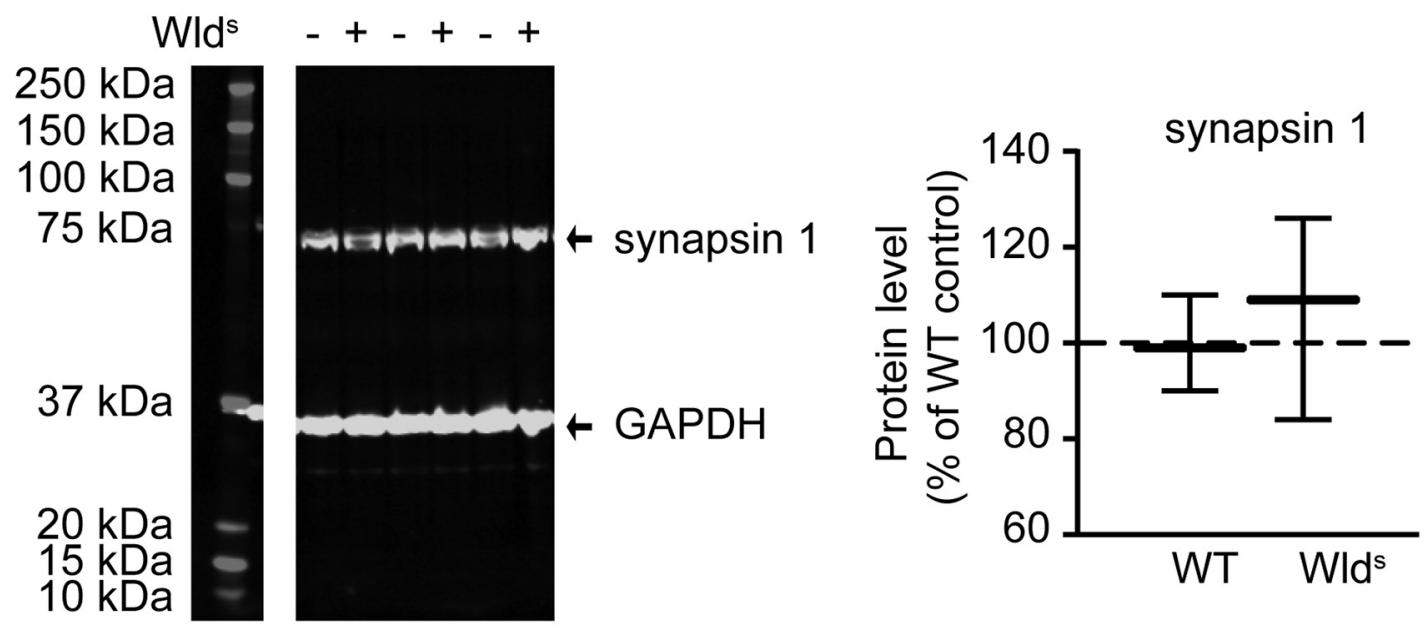

B

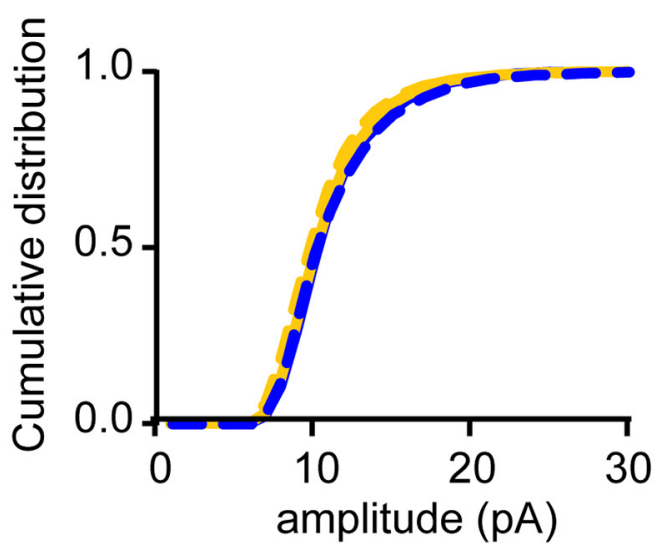

C

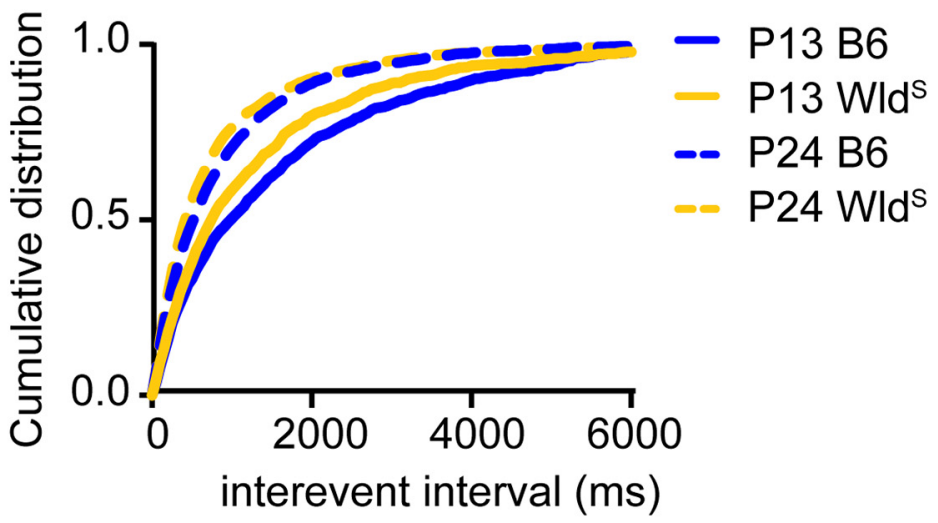

Figure 4. Unaltererd cortical excitation in Wld ${ }^{\mathrm{S}}$ mutant mice. $\boldsymbol{A}$, Representative examples of Western blot analysis of $\mathrm{V} 1$ and quantification of expression levels, normalized to those of wild-type (WT) control mice. Expression levels for synapsin 1 are unaltered at P20 ( $t$ test, $p=0.5091, n=6$ for both genotypes). Values shown as median (solid line), \pm 1.5 interquartile range (box) and minimal and maximal values (whiskers). $\boldsymbol{B}, \boldsymbol{C}$, Cumulative distributions of the amplitude (B) or interevent interval (C) of $\mathrm{mEPSC}$ in Wld ${ }^{\mathrm{S}}$ (yellow) or WT (blue) mice at P13-P14 (solid line) or P24-P25 (dotted line). Excitatory input to pyramidal neurons shows no significant change in amplitude between Wld ${ }^{\mathrm{S}}$ and WT control mice at P13-P14 ( $t$ test, $p=0.55$, WT: $n=10$, Wld $\left.{ }^{\mathrm{S}}: n=5\right)$ or P24-P25 ( $p=0.59$, WT: $n=9$, Wld $\left.{ }^{\mathrm{S}}: n=13\right)$. Frequencies of mEPSCs in WId ${ }^{\mathrm{S}}$ mice and WT controls also show no significant difference between the two genotypes (P13-P14: $p=0.84$, P24-P25: $p=0.23, \mathrm{n}=$ same is as in $\boldsymbol{A}$ ).

C57BI/6Ola/hsd mice, by staining for synaptotagmin-2, a protein selectively expressed by PV + boutons (Sommeijer and Levelt, 2012). Using immunohistochemistry and confocal microscopy, we assessed the density of synaptotagmin-2 puncta at different developmental ages, P20 and P30. However, we did not detect a difference in density of perisomatic synaptotagmin-2 puncta in $\mathrm{Wld}^{\mathrm{S}}$ mice compared to wild-type mice (Fig. $3 A, B$ ). Additionally, we studied whether there is higher expression of synaptotagmin-2. Western blot analysis of V1 from P30 Wld $^{\mathrm{S}}$ and control $\mathrm{C} 57 \mathrm{Bl} / 6 \mathrm{Ola} / \mathrm{hsd}$ mice revealed no difference in synaptotagmin-2 levels (Fig. 3C). These findings suggest that inhibitory innervation through PV+ interneurons is not responsible for the early functional changes in V1 of Wld ${ }^{S}$ mice. To further investigate this, we studied the levels of the glutamic acid decarboxylase
GAD65, an enzyme involved in GABA synthesis. We used quantitative PCR to determine levels of Gad2 mRNA (encoding GAD65) relative to housekeeping genes in V1 from P30 mice but found no difference between WId ${ }^{S}$ and wild-type control mice (Fig. 3D). Thus, our findings do not support the notion that development of GABAergic innervation is accelerated in $\mathrm{Wld}^{\mathrm{S}}$ mice.

Previous studies have shown that also excitatory synapse maturation affects critical period onset and closure (Bochner et al., 2014; Stephany et al., 2014; Huang et al., 2015; Jenks et al., 2017). We therefore studied whether excitatory synapses developed differently in $\mathrm{Wld}^{\mathrm{S}}$ mice. To determine this, we first quantified levels of the presynaptic protein synapsin 1 in dissected $\mathrm{V} 1$ from $\mathrm{Wld}^{\mathrm{S}}$ and control C57BI/6Ola/hsd mice at p20. We found no differences in synapsin 1 levels between these mice (Fig. 4A). 
A

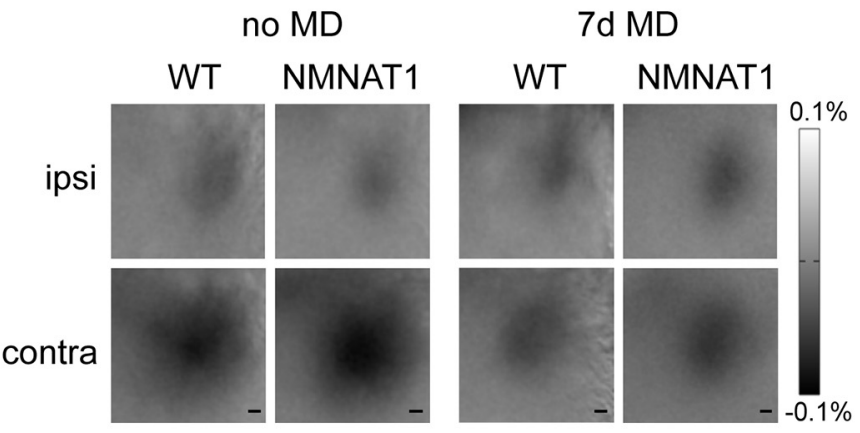

C

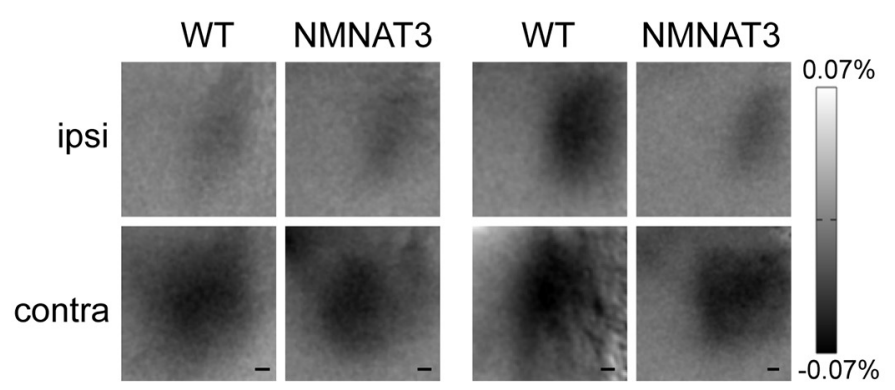

B

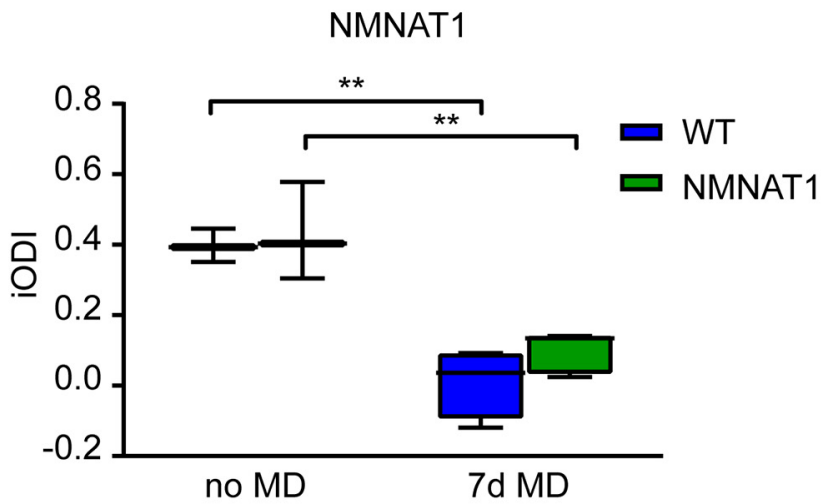

D

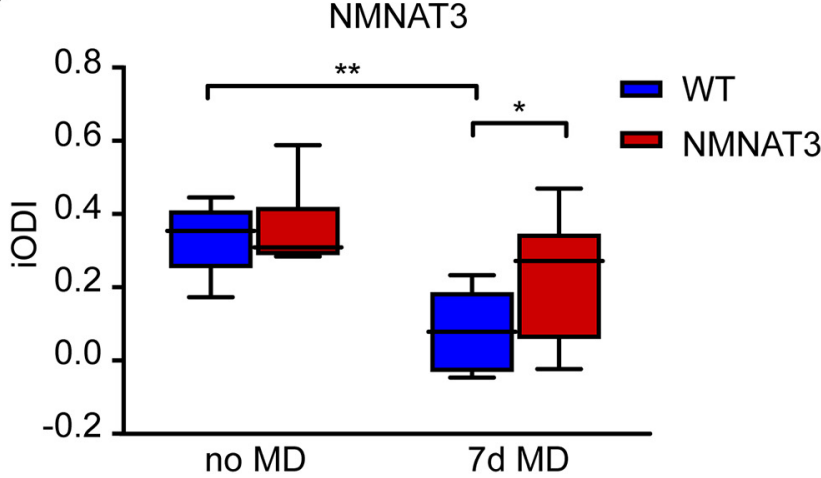

Figure 5. NMNAT3, but not NMNAT1, overexpression reduces OD plasticity. $\boldsymbol{A}$, Transcranial images of change in light reflection in $\mathrm{V} 1$, in response to individual eye stimulation in non-deprived (no MD) and 7 D-deprived (7d MD) wild-type (WT) and NMNAT1 mice. $\boldsymbol{B}$, iODI shows that $7 d \mathrm{~d}$ M during the peak of the critical period induces an OD shift both in WT mice and in NMNAT1 mice (interaction genotype/OD-shift: two-way ANOVA, $p=0.235$; interaction treatment/OD-shift: $p<0.0001$, post hoc Tukey's, WT vs WT MD, $p=$ 0.0033, NMNAT1 vs NMNAT1 MD, $p=0.0015$. WT: $n=3$ mice, NMNAT1: $n=3$, WT MD: $n=4$, NMNAT1 MD: $n=5$ ). $\boldsymbol{C}$, Transcranial images of change in light reflection in V1, in response to individual eye stimulation in no MD and 7d MD WT and NMNAT3 mice. $\boldsymbol{D}$, Imaged ODIs show that 7d MD during the peak of the critical period, induces a larger OD shift in WT mice than in NMNAT3 mice (interaction genotype/OD-shift: two-way ANOVA, $p=0.0475$; interaction treatment/OD-shift: $p<0.0001$, post hoc Tukey's, WT vs WT MD, $p=0.001$, WT MD vs NMNAT3 MD, $p=0.0283$, NMNAT3 vs NMNAT3 MD, $p=0.09$. WT: $n=7$, NMNAT3: $n=8$, WT MD: $n=11$, Wld $\left.{ }^{\mathrm{S}} \mathrm{MD}: n=16\right)$. Values shown as median (solid line), \pm 1.5 interquartile range (box) and minimal and maximal values (whiskers); $* p<0.05, * * p<0.01$.

To also have a functional readout of excitatory synapse development, we measured the amplitude and interevent intervals of mEPSCs in pyramidal neurons in layers $2 / 3$ of V1 in Wld ${ }^{\mathrm{S}}$ and wild-type mice of P13-P14 and P24-P25. We found no differences in mEPSC amplitudes or interevent intervals between Wld ${ }^{S}$ and wild-type mice (Fig. $4 B, C)$. Thus, more rapid excitatory synapse development also does not seem to explain the reduced OD plasticity in P28-P35 Wld ${ }^{\mathrm{S}}$ mice.

\section{NMNAT3, but not NMNAT1, overexpression reduces OD plasticity}

In WId ${ }^{\mathrm{S}}$ mice, a UBE4b-NMNAT1 fusion protein is overexpressed. The effect that this protein has on slowing down Wallerian degeneration depends on its presence in axons (Conforti et al., 2007). However, the Wld ${ }^{\text {S }}$ fusion protein is also present in the nucleus. Endogenous NMNAT1 is a nuclear NAD+ synthase and is involved in transcriptional regulation (Pollak et al., 2007; Chang et al., 2010). It is thus conceivable that the plasticity changes we observe in $\mathrm{Wld}^{\mathrm{S}}$ mice are not caused through the signaling pathway that regulates Wallerian degeneration, but through nuclear NMNAT activity.

To test this possibility, we examined whether OD plasticity was reduced in a transgenic mouse line overexpressing nuclear NMNAT1 (Yahata et al., 2009). Again, we used optical imaging of intrinsic signal to determine OD in NMNAT1 transgenic mice and wild-type littermates that were either reared normally, or monocular deprived for 7 d (P28-P35). We found that OD plasticity occurred normally in NMNAT1-overexpressing mice (Fig. 5A,B), suggesting that the Wld ${ }^{S}$ mutation does not cause accelerated cortical development by directly altering transcriptional control.

To test the alternative hypothesis that increased cytoplasmic NMNAT activity is responsible for decreased OD plasticity toward the end of the critical period, we made use of mice overexpressing NMNAT3. Previous work has shown that in contrast to NMNAT1, overexpression of NMNAT3 slows down Wallerian degeneration, possibly by 
A

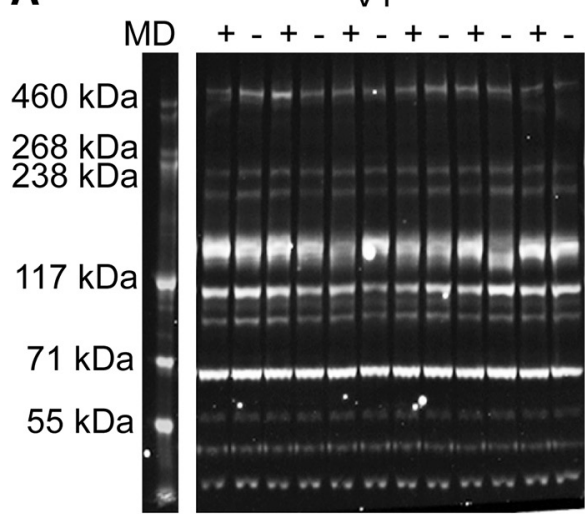

MD -+-+-+-+-+-+-

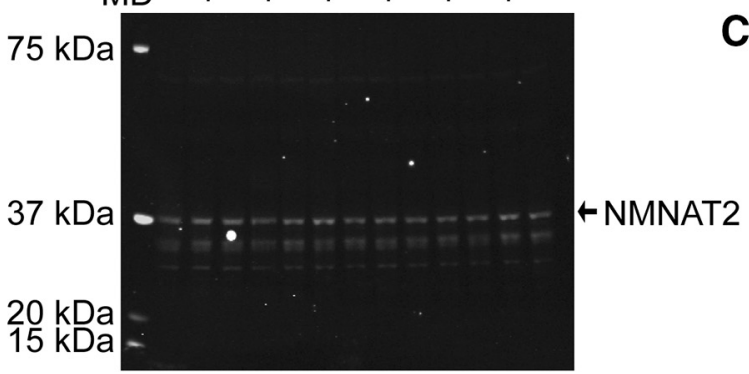

B +MYCBP2

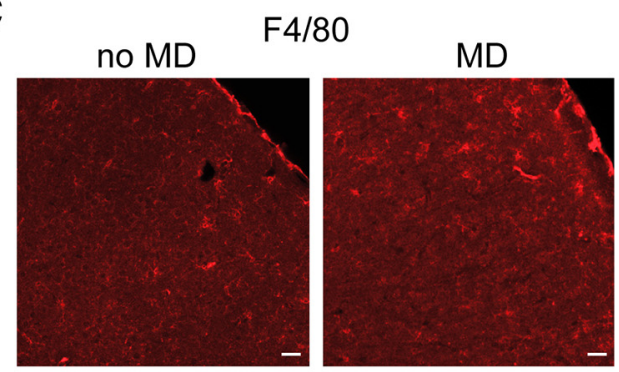

V1
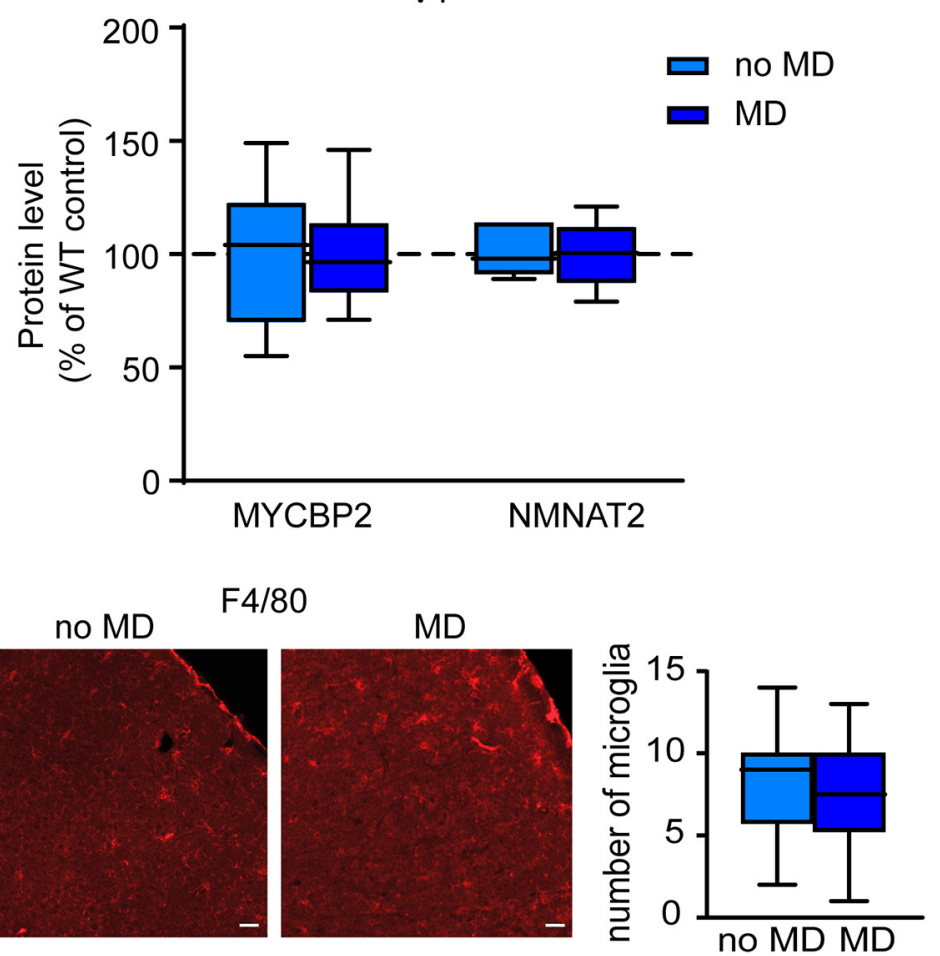

Figure 6. MD does not affect expression of Wallerian degeneration-related proteins. $\boldsymbol{A}$, Representative examples of Western blot analysis of V1 homogenates of wild-type (WT) mice at P37 with (+) or without (-) 7 d MD for MYCBP2 and NMNAT2 expression. $\boldsymbol{B}$, Quantification of expression levels, normalized to those of non-deprived WT control mice. Expression levels for both MYCBP2 and NMNAT2 are unaltered in V1 after MD ( $t$ test, MYCBP2: $p=0.992$, both conditions: $n=6$; NMNAT2: $p=0.985$, no MD: $n=7$, MD: $n=6)$. $C$, Examples and quantification of F4/80 stainings for activated microglia in WT control mice with or without $7 \mathrm{~d}$ MD. The number of activated microglia per $387.5 \times 387.5 \mu \mathrm{m}$ area of $\mathrm{V} 1$ is not significantly different with or without $7 \mathrm{~d}$ MD $(t$ test, $p=0.821$, no MD: $n=4$ mice; MD: $n=3$ mice). Values shown as median (solid line), \pm 1.5 interquartile range (box) and minimal and maximal values (whiskers). Scale bars, $50 \mu \mathrm{m}$.

substituting for cytoplasmic NMNAT2 when it is downregulated (Avery et al., 2009; Yahata et al., 2009). We found that in NMNAT3-overexpressing mice, OD plasticity after $7 \mathrm{~d}$ of MD was significantly reduced (Fig. 5C,D), mimicking the phenotype of Wld ${ }^{S}$ mice. This indicates that the effects observed in Wld ${ }^{S}$ mice are caused by cytoplasmic effects of the UBE4b-NMNAT1 fusion protein rather than by its nuclear activity. These results suggest that the reduction of OD plasticity in WId ${ }^{S}$ mice during the last week of the critical period probably involves a signaling cascade that involves genes that regulate Wallerian degeneration.

\section{MD does not affect expression of Wallerian degeneration-related proteins}

So far, our results show that the signaling pathway that regulates Wallerian degeneration also causes the decline of OD plasticity to occur prematurely in V1. This could imply that OD plasticity actually involves Wallerian degeneration. Alternatively, Wallerian degeneration and cellular events underlying OD plasticity, such as axon growth and retraction and synapse turnover, use partially overlapping signaling cascades. To differentiate between these possibilities, we looked for direct signs of Wallerian degeneration during the induction of OD plasticity, such as the presence of activated microglia, or acute regulation of
MYCBP2 or NMNAT2 protein levels (Babetto et al., 2013). To determine changes in the levels of MYCBP2 and NMNAT2 after MD, we performed quantitative Western blot analysis on $\mathrm{V} 1$ dissected from the contralateral hemisphere of mice that were MD for $7 \mathrm{~d}$ and undeprived littermates. No differences in NMNAT2 or MYCBP2 levels were found between tissue from non-deprived and deprived mice (Fig. $6 A, B$ ). This suggests that OD plasticity does not involve Wallerian degeneration initiated by MYCBP2/NMNAT2 regulation. We also assessed whether OD plasticity resulted in the presence of activated microglia, a hallmark of Wallerian degeneration. We performed immunohistochemistry with the activated microgliaspecific antibody F4/80 (Castaño et al., 1996) on sections of $\mathrm{V} 1$ of $\mathrm{C} 57 \mathrm{BI} / 6 \mathrm{Ola} / \mathrm{hsd}$ mice that had been subjected to $7 \mathrm{~d}$ of MD and undeprived littermates. Assessment of F4/80 stained V1 sections did not reveal a significant increase in active microglia between non-deprived and deprived mice (Fig. 6C,D). Thus, we did not find evidence for Wallerian degeneration occurring during OD plasticity, despite the finding that both events are regulated by NMNAT proteins.

\section{Discussion}

In this study, we show for the first time that genes known for regulating Wallerian degeneration also control 
experience-dependent plasticity during development. We demonstrate that compared to control mice, OD plasticity is lower toward the end of the critical period in Wld ${ }^{S}$ mice and visual acuity increases at an earlier age. Interestingly, we did not find any signs of Wallerian degeneration during OD plasticity, suggesting that these processes share a common signaling pathway but do not necessarily involve the same cellular mechanisms of axon degeneration.

The WId ${ }^{S}$ UBE4b-NMNAT1 fusion protein slows down Wallerian degeneration by mislocalizing NMNAT1 to the cytoplasm (Conforti et al., 2007; Sasaki et al., 2016), where it prevents SARM1-dependent NAD+ depletion that drives axonal disintegration (Sasaki et al., 2016). Endogenous NMNAT1 is expressed in the nucleus however, where it controls NAD+ synthesis and modulates gene transcription (Chang et al., 2010). Our experiments confirm that increased cytoplasmic NMNAT levels also interfere with OD plasticity: in mice overexpressing nuclear NMNAT1, OD plasticity was unaffected while it was reduced in mice overexpressing NMNAT3 which localizes to mitochondria and also reduces Wallerian degeneration (Avery et al., 2009; Yahata et al., 2009). Whether increased cytoplasmic NMNAT reduces OD plasticity through preventing SARM1-dependent NAD+ depletion or through a different signaling cascade remains to be tested.

An earlier study had revealed that axon pruning during development is not altered in WId ${ }^{S}$ mice or flies expressing the $\mathrm{Wld}^{S}$ protein (Hoopfer et al., 2006). This implies that the Wallerian degeneration pathway is only active during pathologic axon retraction and does not regulate physiologic axon retraction during development. The fact that $O D$ plasticity is affected in WId ${ }^{S}$ mice and mice overexpressing NMNAT3 shows that the situation is more complex and that during a later phase of cortical development the Wallerian degeneration signaling pathway does have a role in a physiologic developmental process. We were not able to determine whether the reduced OD plasticity at the end of the critical period was due to a deficit in axon pruning. We did not find any direct evidence for Wallerian degeneration during OD plasticity in V1, such as altered NMNAT2 or MYCBP2 expression (Gilley and Coleman, 2010) or obvious changes in microglia activation. However, it is possible that OD plasticity does not involve the synchronous retraction of a sufficiently large population of cortical axons to cause detectable changes in these markers. Alternatively, NMNAT proteins may not be involved in acute axonal destabilization during OD plasticity, but regulate cortical plasticity by gradually increasing overall axon or synapse stability in the maturing visual cortex.

We found no evidence for activation of microglia after MD. This is in line with a previous study that showed that microglia cells contributed to OD plasticity but did not become activated (Tremblay et al., 2010). However, in this study more subtle changes in microglia morphology and dynamics were observed by in vivo two-photon microscopy after brief MD that were essential for effective OD plasticity (Tremblay et al., 2010). Thus, in contrast to the full microglia activation and degeneration of entire axons in Wallerian degeneration after cortical damage, OD plasticity seems to result in a more subtle process involving partial activation of microglia and limited retraction of axonal branches.

An early decline of OD plasticity has been observed previously in mice overexpressing BDNF (Hanover et al., 1999; Huang et al., 1999). In these mice, the increase in visual acuity that usually occurs between P25 and P35 also happened at an earlier age, as did the maturation of inhibitory innervation. It is thus possible that also in $\mathrm{Wld}^{\mathrm{S}}$ mice, the visual cortex matures faster. We did indeed observe that cortical visual acuity was higher at P25 in $\mathrm{Wld}^{\mathrm{S}}$ mice than in control mice. However, we did not observe a more rapid development of cortical inhibitory innervation in $\mathrm{Wld}^{\mathrm{S}}$ mice. We also did not find evidence for accelerated excitatory synapse development. Possibly, more subtle developmental alterations of the visual system underlie the rapid increase in visual acuity in $\mathrm{Wld}^{\mathrm{S}}$ mice, such as changes in cortical AMPA/NMDA receptor ratios (Saiepour et al., 2017) or thalamic wiring (Stephany et al., 2018). Future studies will have to reveal whether earlier events in visual cortical development, such as transitions in spontaneous activity patterns (Siegel et al., 2012), binocular orientation matching (Wang et al., 2010) or critical period onset (Hensch et al., 1998), also occur at an earlier age in Wld ${ }^{S}$ mice.

In conclusion, this study provides the first evidence that genes in the signaling pathway regulating Wallerian degeneration are also involved in the control of experiencedependent plasticity during normal cortical development. This knowledge may help to reveal the mechanisms involved in critical period closure during cortical development and advance the discovery of novel drug targets for enhancing brain plasticity for therapeutic purposes.

\section{References}

Antonini A, Fagiolini M, Stryker MP (1999) Anatomical correlates of functional plasticity in mouse visual cortex. J Neurosci 19:4388406. Medline

Araki T, Sasaki Y, Milbrandt J (2004) Increased nuclear NAD biosynthesis and SIRT1 activation prevent axonal degeneration. Science 305:1010-1013. CrossRef

Avery MA, Sheehan AE, Kerr KS, Wang J, Freeman MR (2009) WId S requires Nmnat1 enzymatic activity and N16- VCP interactions to suppress Wallerian degeneration. J Cell Biol 184:501-513. CrossRef Medline

Babetto E, Beirowski B, Russler E, Milbrandt J, DiAntonio A (2013) The Phr1 ubiquitin ligase promotes injury-induced axon selfdestruction. Cell Rep 3:1422-1429. CrossRef Medline

Bear MF, Singer W (1986) Modulation of visual cortical plasticity by acetylcholine and noradrenaline. Nature 320:172-176. CrossRef Medline

Bochner DN, Sapp RW, Adelson JD, Zhang S, Lee H, Djurisic M, Syken J, Dan Y, Shatz CJ (2014) Blocking PirB up-regulates spines and functional synapses to unlock visual cortical plasticity and facilitate recovery from amblyopia. Sci Transl Med 6:258ra140. CrossRef Medline

Castaño A, Lawson LJ, Fearn S, Perry VH (1996) Activation and proliferation of murine microglia are insensitive to glucocorticoids in Wallerian degeneration. Eur J Neurosci 8:581-588. Medline

Chang J, Zhang B, Heath H, Galjart N, Wang X, Milbrandt J (2010) Nicotinamide adenine dinucleotide (NAD)-regulated DNA methylation alters CCCTC-binding factor (CTCF)/cohesin binding and 
transcription at the BDNF locus. Proc Natl Acad Sci USA 107: 21836-21841. CrossRef Medline

Chattopadhyaya B, Di Cristo G, Higashiyama H, Knott GW, Kuhlman SJ, Welker E, Huang ZJ (2004) Experience and activity-dependent maturation of perisomatic GABAergic innervation in primary visual cortex during a postnatal critical period. J Neurosci 24:9598-9611. CrossRef Medline

Coleman MP, Freeman MR (2010) Wallerian degeneration, wld(s), and nmnat. Annu Rev Neurosci 33:245-267. CrossRef Medline

Coleman MP, Conforti L, Buckmaster EA, Tarlton A, Ewing RM, Brown MC, Lyon MF, Perry VH (1998) An 85-kb tandem triplication in the slow Wallerian degeneration (Wlds) mouse. Proc Natl Acad Sci USA 95:9985-9990. Medline

Conforti L, Tarlton A, Mack TG, Mi W, Buckmaster EA, Wagner D, Perry VH, Coleman MP (2000) A Ufd2/D4Cole1e chimeric protein and overexpression of Rbp7 in the slow Wallerian degeneration (WldS) mouse. Proc Natl Acad Sci USA 97:11377-11382. CrossRef Medline

Conforti L, Fang G, Beirowski B, Wang MS, Sorci L, Asress S, Adalbert R, Silva a, Bridge K, Huang XP, Magni G, Glass JD, Coleman MP (2007) $\mathrm{NAD}(+)$ and axon degeneration revisited: Nmnat1 cannot substitute for WId(S) to delay Wallerian degeneration. Cell Death Differ 14:116-127. CrossRef Medline

Conforti L, Wilbrey A, Morreale G, Janeckova L, Beirowski B, Adalbert R, Mazzola F, Di Stefano M, Hartley R, Babetto E, Smith T, Gilley J, Billington RA, Genazzani AA, Ribchester RR, Magni G, Coleman M (2009) Wld S protein requires Nmnat activity and a short $\mathrm{N}$-terminal sequence to protect axons in mice. J Cell Biol 184:491-500. CrossRef Medline

Dahlhaus M, Wan Li K, van der Schors RC, Saiepour MH, van Nierop P, Heimel JA, Hermans JM, Loos M, Smit AB, Levelt CN (2011) The synaptic proteome during development and plasticity of the mouse visual cortex. Mol Cell Proteomics 10:M110.005413. CrossRef Medline

del Río JA, de Lecea L, Ferrer I, Soriano E (1994) The development of parvalbumin-immunoreactivity in the neocortex of the mouse. Science 5:247-259. CrossRef Medline

Fagiolini M, Fritschy J-M, Löw K, Möhler H, Rudolph U, Hensch TK (2004) Specific GABAA circuits for visual cortical plasticity. Science 303:1681-1683. CrossRef Medline

Geden MJ, Deshmukh M (2016) Axon degeneration: context defines distinct pathways. Curr Opin Neurobiol 39:108-115. CrossRef Medline

Gerdts J, Summers DW, Milbrandt J, DiAntonio A (2016) Axon selfdestruction: new links among SARM1, MAPKs, and NAD+ metabolism. Neuron 89:449-460. CrossRef Medline

Gianfranceschi L, Siciliano R, Walls J, Morales B, Kirkwood A, Huang ZJ, Tonegawa S, Maffei L (2003) Visual cortex is rescued from the effects of dark rearing by overexpression of BDNF. Proc Natl Acad Sci USA 100:12486-12491. CrossRef Medline

Gilley J, Coleman MP (2010) Endogenous Nmnat2 is an essential survival factor for maintenance of healthy axons. PLoS Biol 8 . CrossRef Medline

Gordon A, Stryker P (1996) Experience-dependent plasticity of binocular responses in the primary visual cortex of the mouse. $J$ Neurosci 76:3274-3286. CrossRef Medline

Hanover JL, Huang ZJ, Tonegawa S, Stryker MP (1999) Brainderived neurotrophic factor overexpression induces precocious critical period in mouse visual cortex. J Neurosci 19:RC40. CrossRef Medline

Haruta M, Hata Y (2007) Experience-driven axon retraction without binocular imbalance in developing visual cortex. Curr Biol 17:3742. CrossRef Medline

Heimel JA, Hartman RJ, Hermans JM, Levelt CN (2007) Screening mouse vision with intrinsic signal optical imaging. Eur J Neurosci 25:795-804. CrossRef Medline

Hensch TK (2005) Critical period plasticity in local cortical circuits. Nat Rev Neurosci 6:877-888. CrossRef Medline
Hensch TK, Fagiolini M, Mataga N, Stryker MP, Baekkeskov S, Kash SF (1998) Local GABA circuit control of experience-dependent plasticity in developing visual cortex. Science 282:1504-1508. Medline

Hofer SB, Mrsic-Flogel TD, Bonhoeffer T, Hübener M (2006) Lifelong learning: ocular dominance plasticity in mouse visual cortex. Curr Opin Neurobiol 16:451-459. CrossRef Medline

Hoopfer ED, McLaughlin T, Watts RJ, Schuldiner O, O'Leary DDM, Luo $L$ (2006) Wlds protection distinguishes axon degeneration following injury from naturally occurring developmental pruning. Neuron 50:883-895. CrossRef Medline

Huang X, Stodieck SK, Goetze B, Cui L, Wong MH, Wenzel C, Hosang L, Dong Y, Löwel S, Schlüter OM (2015) Progressive maturation of silent synapses governs the duration of a critical period. Proc Natl Acad Sci USA 112:E3131-E3140. CrossRef Medline

Huang ZJ, Kirkwood A, Pizzorusso T, Porciatti V, Morales B, Bear MF, Maffei L, Tonegawa S (1999) BDNF regulates the maturation of inhibition and the critical period of plasticity in mouse visual cortex. Cell 98:739-755. CrossRef Medline

Jenks KR, Kim T, Pastuzyn ED, Okuno H, Taibi AV, Bito H, Bear MF, Shepherd JD (2017) Arc restores juvenile plasticity in adult mouse visual cortex. Proc Natl Acad Sci USA 114:201700866. CrossRef Medline

Kerschensteiner M, Schwab ME, Lichtman JW, Misgeld T (2005) In vivo imaging of axonal degeneration and regeneration in the injured spinal cord. Nat Med 11:572-577. CrossRef Medline

Kuhlman SJ, Olivas ND, Tring E, Ikrar T, Xu X, Trachtenberg JT (2013) A disinhibitory microcircuit initiates critical-period plasticity in the visual cortex. Nature 501:543-546. CrossRef Medline

Lehmann K, Löwel S (2008) Age-dependent ocular dominance plasticity in adult mice. PLoS One 3:e3120. CrossRef Medline

Levelt CN, Hübener M (2012) Critical-period plasticity in the visual cortex. Annu Rev Neurosci 35:309-330. CrossRef Medline

Lohmann C, Kessels HW (2014) The developmental stages of synaptic plasticity. J Physiol 592:13-31. CrossRef Medline

Lunn ER, Perry VH, Brown MC, Rosen H, Gordon S (1989) Absence of Wallerian degeneration does not hinder regeneration in peripheral nerve. Eur J Neurosci 1:27-33. Medline

Lyon MF, Ogunkolade BW, Brown MC, Atherton DJ, Perry VH (1993) A gene affecting Wallerian nerve degeneration maps distally on mouse chromosome 4. Proc Natl Acad Sci USA 90:9717-9720. Medline

McGee AW, Yang Y, Fischer QS, Daw NW, Strittmatter SH (2005) Experience-driven plasticity of visual cortex limited by myelin and nogo receptor. Science 309:2222-2226. CrossRef Medline

Morishita H, Hensch TK (2008) Critical period revisited: impact on vision. Curr Opin Neurobiol 18:101-107. CrossRef Medline

Pease SE, Segal RA (2014) Preserve and protect: maintaining axons within functional circuits. Trends Neurosci 37:572-582. CrossRef Medline

Pham TA, Graham SJ, Suzuki S, Barco A, Kandel ER, Gordon B, Lickey ME (2004) A semi-persistent adult ocular dominance plasticity in visual cortex is stabilized by activated CREB. Learn Mem 11:738-747. CrossRef Medline

Pizzorusso T, Medini P, Berardi N, Chierzi S, Fawcett JW, Maffei L (2002) Reactivation of ocular dominance plasticity in the adult visual cortex. Science 298:1248-1251. CrossRef Medline

Pollak N, Dölle C, Ziegler M (2007) The power to reduce: pyridine nucleotides - small molecules with a multitude of functions. Biochem J 402:205-218. CrossRef Medline

Saiepour MH, Min R, Kamphuis W, Heimel JA, Levelt CN (2017) $\beta$-Catenin in the adult visual cortex regulates NMDA-receptor function and visual responses. Cereb Cortex 28:1183-1194. CrossRef Medline

Sasaki Y, Araki T, Milbrandt J (2006) Stimulation of nicotinamide adenine dinucleotide biosynthetic pathways delays axonal degeneration after axotomy. J Neurosci 26:8484-8491. CrossRef Medline

Sasaki Y, Nakagawa T, Mao X, DiAntonio A, Milbrandt J (2016) NMNAT1 inhibits axon degeneration via blockade of SARM1mediated NAD+ depletion. Elife 5. CrossRef Medline 
Sato M, Stryker MP (2008) Distinctive features of adult ocular dominance plasticity. J Neurosci 28:10278-10286. CrossRef Medline

Sawtell NB, Frenkel MY, Philpot BD, Nakazawa K, Tonegawa S, Bear MF (2003) NMDA receptor-dependent ocular dominance plasticity in adult visual cortex. Neuron 38:977-985. Medline

Siegel F, Heimel JA, Peters J, Lohmann C (2012) Peripheral and central inputs shape network dynamics in the developing visual cortex in vivo. Curr Biol 22:253-258. CrossRef Medline

Sommeijer JP, Levelt CN (2012) Synaptotagmin-2 is a reliable marker for parvalbumin positive inhibitory boutons in the mouse visual cortex. PLoS One 7:e35323. CrossRef Medline

Stephany CE, Chan LLH, Parivash SN, Dorton HM, Piechowicz M, Qiu S, McGee AW (2014) Plasticity of binocularity and visual acuity are differentially limited by Nogo receptor. J Neurosci 34:1163111640. CrossRef Medline

Stephany CÉ, Ma X, Dorton HM, Wu J, Solomon AM, Frantz MG, Quu S, McGee AW (2018) Distinct circuits for recovery of eye dominance and acuity in murine amblyopia. Curr Biol 28:1914-1923.e5. CrossRef Medline

Syken J, GrandPre T, Kanold PO, Shatz CJ (2006) PirB restricts ocular-dominance plasticity in visual cortex. Science 313:17951800. CrossRef Medline
Tognini P, Putignano E, Coatti A, Pizzorusso T (2011) Experiencedependent expression of miR-132 regulates ocular dominance plasticity. Nat Neurosci 14:1237-1239. CrossRef Medline

Tremblay MÈ, Lowery RL, Majewska AK (2010) Microglial interactions with synapses are modulated by visual experience. PLoS Biol 8. CrossRef Medline

Tropea D, Majewska AK, Garcia R, Sur M (2010) Structural dynamics of synapses in vivo correlate with functional changes during experience-dependent plasticity in visual cortex. J Neurosci 30: 11086-11095. CrossRef Medline

Vargas ME, Barres BA (2007) Why is Wallerian degeneration in the CNS so slow? Annu Rev Neurosci 30:153-179. CrossRef Medline

Vetencourt JFM, Sale A, Viegi A, Baroncelli L, De Pasquale R, O'Leary OF, Castren E, Maffei L (2008) The antidepressant fluoxetine restores plasticity in the adult visual cortex. Science 320: 385-388. CrossRef Medline

Wang BS, Sarnaik R, Cang J (2010) Critical period plasticity matches binocular orientation preference in the visual cortex. Neuron 65: 246-256. CrossRef Medline

Yahata N, Yuasa S, Araki T (2009) Nicotinamide mononucleotide adenylyltransferase expression in mitochondrial matrix delays Wallerian degeneration. J Neurosci 29:6276-6284. CrossRef Medline 